Bakas, F. E., N. Duxbury, and S. Albino. (Forthcoming). Creative tourism microentrepreneurs in Portugal. In Duarte B. Morais (Ed.), Tourism Microentrepreneurship: Evidence-based Strategies to Develop and Integrate the Informal Supply Sector for Improved Destination Equity, Sustainability, and Competitiveness. "Bridging Tourism Theory and Practice" series. Bingley, England: Emerald Publishing.

\title{
CREATIVE TOURISM MICROENTREPRENEURS IN PORTUGAL
}

Fiona Eva Bakas

Centre for Social Studies, University of Coimbra, Portugal

Nancy Duxbury

Centre for Social Studies, University of Coimbra, Portugal

Sara Albino

CIDEHUS, University of Évora, Portugal

\begin{abstract}
When researching the role of microentrepreneurship in equitable and sustainable development, the question of how tourism microentrepreneurs forge relationships between place, community, and resources is significant. Two case studies from CREATOUR, a project investigating creative tourism, a novel type of cultural tourism that includes active participation in creative activities and connection to place, bring to light how these relationships are developed and implemented. Findings indicate that creative tourism microentrepreneurs' activities in two small cities are being shaped by, and shaping, place in multifaceted ways. Creative tourism activities stimulate new perspectives on place, are designed synergistically with the 'seasonal' fluctuations of the type of visitors, are embedded in personal networks of collaborators, and actively encourage alternative patterns of tourism consumption.
\end{abstract}

KEYWORDS: creative tourism, small cities, creative economy, CREATOUR, Portugal

\section{BIOSKETCH:}

Fiona Eva Bakas, $\mathrm{PhD}$, fionabakas@ces.uc.pt, is a critical tourism researcher with international teaching experience. She holds a PhD in Tourism (Otago University, 2014), has 20 years of varied work experience (corporate and academic) and is now a contracted postdoctoral researcher in a nation-wide project on creative tourism in rural areas and small cities (CREATOUR), at the Centre for Social Studies of the University of Coimbra, Portugal. Her research interests are: creative and cultural tourism, gender in tourism labor, qualitative methodologies, cultural mapping, handicrafts, entrepreneurship, rural tourism, and ecotourism.

Nancy Duxbury, PhD, duxbury@ces.uc.pt, is a senior researcher and co-coordinator of the Cities, Cultures and Architecture Research Group at the Centre for Social Studies, University of Coimbra, Portugal. She is Principal Investigator of the CREATOUR project, a member of the European Expert Network on Culture, and an Adjunct Professor at Simon Fraser University and Thompson Rivers University, Canada. Her research interests include culture in local sustainable development; culturebased development models in smaller communities; cultural indicators; and cultural mapping, which bridges academic inquiry, community practice, and artistic approaches to understand and articulate place.

Sara Albino, PhD, saralb@uevora.pt, is a researcher of the School of Social Sciences at the University of Évora in the field of tourism planning studies. She is an integrated researcher and Scientific 
Council member of the research centre CIDEHUS and a member of the UNESCO Chair team in "Intangible Heritage and Traditional Know-How: Linking Heritage" (University of Évora, Portugal). She is also a member of CIEBA: Research Centre in Studies of Fine Arts (University of Lisbon) and co-founder of Buinho Creative Hub, the Rural Fablab of Baixo Alentejo.

\section{INTRODUCTION}

This chapter responds to the need for research on the role of microentrepreneurship in equitable and sustainable development. Focusing on the often under-researched topic of creative tourism microentrepreneurs in extra-metropolitan areas, this chapter provides knowledge that can help sustainably develop these areas, which often suffer from dwindling populations and a lack of opportunities for decent work. There is a pressing need to consider extra-metropolitan areas and 'the countryside' as places where the creative economy is differently manifested and articulated from the now standard 'creative script' based on large cities (Bell and Jayne, 2010). Taking the position that we are situated within a place-based world (Hildreth and Bailey, 2014), heavily influenced by a combination of geography, history, culture, and inter-linked institutions, fits well within this critical analysis of microentrepreneurship. Delivering a place-based approach is often made difficult by fuzzy boundaries between ecosystems and administrative jurisdictions, which sometimes bear little resemblance to public perceptions and values of place. Furthermore, the applicability of the 'rational economic man' model (Barker and Kuiper, 2003) is now critiqued, especially within female entrepreneurship literature (Ahl and Marlow, 2012), with growing acknowledgement of the influence of surroundings and context on entrepreneurial behavior. Female entrepreneurs in particular are conceptualized as affected by their surroundings and embedded within cultural contexts (Bakas, 2014).

Creative tourism is a novel interpretation of cultural tourism, containing the four dimensions of active participation, creative self-expression, learning, and connection to the local community (Duxbury, 2020) and focusing on co-preserving local traditions while developing creative skills with the local community (Richards, 2011). Creative tourism responds to contemporary motivations of travellers seeking meaningful and transformative experiences, and to be actively involved in the "everyday culture' of the place that they visit through interactive experiences that are connected to place (Richards, 2018). While not a mass market with significant economic impacts in urban and traditional holiday locales, creative tourism is becoming significant in more and more places, especially extrametropolitan areas, by fostering significant 'soft' impacts, such as increased community engagement and cultural sustainability (Duxbury and Richards, 2019).

Creative tourism research is a relatively young and dynamic field informed by the disciplines of tourism, cultural heritage, cultural development, creativity, cultural geography, and local and regional development. CREATOUR is a three and a half-year (2016-2020) research-and-application project focusing on creative tourism that involves five research centers working with 40 participating organizations, referred to here as pilots, located in small cities and rural areas across Portugal in the Norte, Centro, Alentejo, and Algarve regions (Figure 1). A wide range of organizations were selected as pilots, including not-for-profit art and cultural associations, small entrepreneurial businesses, municipalities, regional development associations, and a few multi-organizational partnerships, out of which ten can be classified as independent microentrepreneurs. The CREATOUR project encourages experimental practices and trials to more fully understand creative tourism's issues and potential in extra-metropolitan areas in Portugal. On the research side, the project aims to examine and reflect on the creative tourism activities, including development dynamics and patterns, reception experiences, and community impacts. On the practice side, it aims to catalyze creative tourism offers in small cities and rural areas in Portugal, inform and learn from their development, and link them with each other 
through the development of a national network. In time, the project also aims to inform policy development relating to creative tourism (Bakas and Duxbury, 2018).

\section{INSERT FIGURE 1 AROUND HERE}

Figure 1. CREATOUR Research Centres and Pilots (Participating Organizations) in Portugal (Source: CREATOUR and www.mapsopensource.com)

Microentrepreneurs who offer creative tourism products in smaller, often remote, places are often heavily influenced by their surroundings and place-specific traditions, and embedding local specificities into creative tourism offers appears to be a strategic differentiating factor in providing a distinctive tourism offer (Duxbury, Silva, and Castro, 2019). However, we have found there is limited research on the nuances of how their environment or 'the place' influences how microentrepreneurs actually develop and implement creative tourism offers in a small city, extra-metropolitan context. This motivated us to conduct more in-depth research into the nuances of how a place-based economy influences creative tourism microentrepreneurs' activity development in extra-metropolitan contexts.

Perceiving tourism microentrepreneurs as a significant part of the tourism economy, this research investigates how the place shapes the creative tourism activities microentrepreneurs develop and, in turn, how they actively shape the place in which they operate. We focus on two in-depth case studies of creative tourism microentrepreneurs: VIC//Aveiro Arts House and VAGAR Walking Tours, which are located, respectively, in small towns in the Centro and Alentejo regions of Portugal. Both microentrepreneurs began offering creative tourism activities since joining CREATOUR as pilots. Knowledge co-created within interviews, on-site participant observations, and book chapter cowriting sessions inform this critical analysis of how the place-embeddedness of creative tourism microentrepreneurship influences the development and implementation of creative tourism offers.

\section{MICROENTREPRENEURSHIP AND SMALL CITY CONTEXTS}

In recent years, the popularity of tourism development programs which have microentrepreneurship as their goal has increased, as there is strong consensus that microenterprise contributes to the economic development of both developed and developing countries (Townsend et al., 2016). In development literature, microenterprises are as diverse as sidewalk merchandising, handicraft production, and shop-ownership (Chandy and Narasimhan, 2011). For the purpose of this chapter, microentrepreneurs are defined as self-employed individuals with fewer than five employees (Vial and Hanoteau, 2015).

A general definition of an entrepreneur is "someone who perceives an opportunity and creates an organization to pursue it" (Bygrave, 1997, p. 2). Since the shift towards neoliberal individualism, entrepreneurship is increasingly perceived as the "foundation of opportunistic individualism" (Ahl and Marlow, 2012, p. 544) and simultaneously as an economic activity that offers the potential for creativity and innovation, free from organizational constraints. Both the theory and practice of entrepreneurship have failed to account fully for the role of the social and environmental context. Contextualization is generally limited to treating the social and ecological environment as exogenous forces to which organizations must respond to while pursuing profits, competitive advantage, and other more central objectives. However, by perceiving the economy as a cultural and social formation rather than just a site of exchange of labor (Ateljevic and Doorne, 2003), the mere act of engaging in entrepreneurship can also produce social change. For example, work on female tourism entrepreneurs in Greece (Bakas, 2017) finds that gender roles governing risk-taking behaviours leads female entrepreneurs to be more resilient during a macro-economic crisis.

\section{PARTICIPATORY PLACE-MAKING}

Place can be defined as a set of material and social practices that enact a location (Cresswell, 2006). A 'sense of place' speaks to an insider's attachment to a physical, social, and/or cultural place, and links to individual and collective identity (Davenport and Anderson, 2005). In a time of high mobility, place-based tourism initiatives allow tourists to develop feelings of belonging (Stock, 2006), converting strange places into identifiable, familiar, and functional places. Place influences entrepreneurial activities in economic as well as socialized, experiential, material, and other 
dimensions, which may enable and constrain entrepreneurial activities in different ways. A placebased approach to entrepreneurship can reveal how entrepreneurs create value by linking their business models directly to the unique resources and 'sense of place' associated with a particular locale (Di Gregorio, 2017).

Geographical location is significant for tourism microentrepreneurs. For example, within rural areas an entrepreneur's relations within the community are very important in configuring economic process (McKeever, Anderson, and Jack, 2014). Recent research finds that social embeddedness, which can be summarized as the nature, depth, and extent of an individuals' ties to a community, is highly significant for the success of creative tourism microentrepreneurs located in extra-metropolitan contexts (Bakas, Duxbury, and Castro, 2019). Also, in a rural context, placial embeddedness, defined as an intimate knowledge of and concern for the place, is found to be important in creating entrepreneurial opportunities (Korsgaard, Ferguson, and Gaddefors, 2015).

Grassroots, participatory place-making is defined as how a cultural group imprints its values and traditions on a landscape, giving meaning to geographic space. Contrary to the perspective that 'unintentional worldmaking' (Hollingshead, Ateljevic, and Ali, 2009) occurs, participatory placemaking posits that tourism agents, as active place profilers and co-creators with visitors and residents, have the ability to shape the experiences of visitors and their perception of particular aspects of the landscape through discourse and symbolic interactivity (Mueller and Schade, 2012). Little is known, however, on how tourism microentrepreneurs are forging relationships between place, community, and resources.

\section{STUDY METHODS}

Responding to the gap in literature on the nuances of how tourism microentrepreneurs' places influence how they develop and implement tourism offers in small city contexts, two main research questions guide this book chapter: How are creative tourism microentrepreneurs' business practices and activities for tourists shaped by place? In turn, how do creative tourism microentrepreneurs actively shape their places?

Two case studies are investigated. A case study approach is chosen as it is an intensive method that allows us to investigate the phenomenon in its real-life context and can provide the high level of detail, richness, and variance needed in order to answer the research questions (Flyvbjerg, 2011). Through a continued proximity to the studied reality and the feedback of those studied (Yin, 2009) allowed the nuances of creative tourism microentrepreneurs' place-based connections to be better understood.

The data was collected in 2018-2019 and arises from multiple sources. Annual on-site visits, held during the time of selected creative tourism implementations, offered moments for participant observation and in situ interviews with the pilots. On-site visits provided an opportunity for the researcher to 'live' the creative tourism project and have an immersive experience which allowed for a better understanding of the pilot and its activity development processes. Monthly meetings were established with some pilots in order to maintain regular contact and follow the development process of creative tourism activities. These monthly meetings were in the form of Skype or Facetime calls and had a duration of an hour. The pilots' insights and perspectives were also captured through interviews carried out specifically for this chapter in April 2019, and through collaborative writing of chapters for the project's final book. Selected data from these sources was brought together and thematically analysed for this chapter.

\section{MICROENTREPRENEURS BEING AFFECTED BY AND AFFECTING PLACE}

This section presents two case studies as well as an analysis and discussion of two main strands of enquiry: (1) how creative tourism microentrepreneurs' activities are shaped by the place in which they operate; and (2) how creative tourism microentrepreneurs actively shape their place. 


\section{Case Study 1: VIC//Aveiro Arts House}

VIC//Aveiro Arts House is located in a small seaside city in central Portugal, Aveiro, population 78,540 (PORDATA, 2011). The organization is based in a five-storey building that combines a local themed tourist accommodation space, an artistic residence and co-work space, a cultural space with a small auditorium, and a gallery where cultural events and training events take place. The location has historical significance for the city: "Built in 1969, this auditorium played the role of a clandestine cinema during the fascist regime. The building was the residence of the artist Vasco Branco (19192014) and is filled with works of art and period furniture." The organization is run by Hugo Branco, the grandson of Vasco Branco.

Hugo takes on a variety of roles, including tourism microentrepreneur, sound artist, and cultural programmer. Through speaking to creative people in Aveiro to see what was missing in the community, he identified the lack of a local network for creatives. Consequently, VIC//Aveiro Arts House was created as a space where creatives can meet, exchange opinions, and co-create, rather than creating in isolation. Hugo recounts: "One of the first things that we did was to try to create a safe haven for these creative people and projects." Since November 2016, VIC//Aveiro Arts House has organized small concerts, movie screenings, poetry sessions, dinner parties, and talks featuring national and international artists. According to Hugo, these events have played an important role in creating a 'safe haven' for creatives: "The concerts and movie sessions that they held in the house, more than just wanting to create cultural programming in the city, which was interesting because there was a lack of some kinds of events, but also our main objective was to get these people together. To be together and to start naturally talking and see what comes out of this."

Creative Tourism Activities Held in VIC//Aveiro Arts House. VIC//Aveiro Arts House joined CREATOUR in 2018, and has created a set of creative tourism activities called 'Tools of the trade' ('Ossos do oficio' in Portuguese), which have included "workshops in ceramics, video editing, screenwriting and vocal improvization, creative writing, construction of musical instruments, gastronomy, performative arts, curatorship and cultural management, training actions and workshops." The creative tourism activities organized by VIC//Aveiro Arts House are largely taught by visiting artists. As Hugo says, "While it is not mandatory, artists in residence are encouraged to give at least one public presentation, performance, exhibition, workshop, or lead a similar event during their residency."

An example of a creative tourism activity organized at VIC//Aveiro Arts House is the 'Noise Puppets Workshop', which was held March 11-12, 2019, with Martí Guillem, a visiting artist. This was a twoday workshop to transform an incredible soft and cute puppet into a noisy and bizarre sound device (Figure 2). Participants were taught what a circuit, an electronic component, resistors, condensers, switches, LEDs, pots, diodes, connectors, and body contacts were and how they could be used. They were also taught about amplification, feedback, and distortion and how they could be used in a creative way.

\section{INSERT FIGURE 2 AROUND HERE}

Figure 2. Poster for the Noise Puppets Workshop at VIC//Aveiro Arts House (Source: VIC//Aveiro Arts House)

Activity Being Shaped by Place. The creative tourism activities organized by VIC//Aveiro Arts House are shaped by the place in which it is located, and Hugo's personal artistic activities and networks play a big role in the activities offered; as he says, "sound art is something we are very involved with in the house and this inspired many of the workshops." His choice of making workshops with a focus on sound art was also influenced by the identification of a lack of this art in Aveiro. As Hugo says, "There is a lack of this programming in the city, so since the beginning we tried to bring a kind of programming that didn't exist in the city."

The activities of creative tourism microentrepreneurs are also shaped by the type of visitors to the city. In the winter, as a university town, the public is mainly made up of students and researchers who stay for at least a few months. In the summer, as Aveiro is known as 'the Venice of Portugal' for its 
canals and canal-boats, the public is made up of international, short-stay tourists. These characteristics are shaping the creation of 'seasonal' creative tourism activities that are of longer duration in the winter and shorter duration in the summer, to match changes in the available public/clients: "Longer, more in-depth workshops for the winter, when the public is students, and researchers and people who can take a few days off to do such a workshop. Then shorter, mini-versions for the summer, maybe of about 2-3 hours long, such as the travel-writing workshop and maybe the serigraphy one too."

Activities Shaping Place. One of the ways in which the creative tourism activities of VIC//Aveiro Arts House influence its place is by potentially changing the type of visitors that come to Aveiro. Hugo says he is "interested in getting people to stay in Aveiro longer than just a day-trip," and by offering two-day workshops, visitors are encouraged to stay longer in Aveiro, a place that is largely seen as a one-day destination. While at the moment, the creative tourism activities are sporadic and scattered, a more concerted effort to create a continuous offer of workshops could shape Aveiro as a tourist destination known for its creative tourism workshops. As Hugo says, "What we are doing now is not continuous, one workshop here and there... but if people know that there is a more ongoing workshops happening in Aveiro, the city can benefit a lot from that." Another way in which creative tourism activities potentially shape the place is by empowering locals to become cultural programmers and thus increase the critical mass needed to attract more tourists. Hugo wants to create "more workshops that are more connected to cultural management, curatorship, audience development and this is stuff that can bring people from other parts of the country, but also very important for the people who live in the city." This type of action could enhance the visibility of Aveiro as cultural tourism destination. Hugo also plans to develop a co-creation space in cooperation with the municipality and the university where locals, the local temporary population (e.g., students and researchers), and tourists could create workshops for each other and share knowledge. Hugo says this would promote alternative economic transactions: "The ideal would be to transcend commercial dynamics - the relationships that you develop within a non-economic context are much deeper and more interesting."

\section{Case Study 2: VAGAR Walking Tours}

Located in the city of Évora, a UNESCO World Heritage site with about 56,600 inhabitants (PORDATA, 2011), Évora experiences mass cultural tourism largely in the form of day-trips with a low average rate of overnight stays of 1.6 nights (Serra et al., 2017).

VAGAR Walking Tours is registered as a tourism 'animation' company in Évora. The founder of VAGAR Walking Tours, Melanie Volfram, and her business partner, Diane de Camproger, have a deep interest in archeology, built heritage, and local practices of intangible cultural heritage, such as horse riding and gastronomy. Diane organizes programs related to horse traditions, while Melanie focuses on themes related to marble and archeology. As Melanie notes, "our life circumstances took us to the area of tourism."

The name of this tourism microventure, VAGAR Walking Tours, was inspired by the Portuguese word vagar that, according to the entrepreneur, has a regional symbolic meaning corresponding to idiomatic expressions in Alentejo: 'to do things without rushing' (fazer coisas com vagar) or 'to have time' (ter vagar). The company's main activity is to provide unhurried walking tours and related activities in the central Alentejo region for small groups of tourists. Compared to other local tourism companies that frame each tourism experience within a pre-determined schedule and timeframe of a few hours, VAGAR Walking Tours organizes its activities without fixed end times. As they explain, "we can have activities that take an entire afternoon or day - we do things without rushing. The concept of time is something specific in the culture of Alentejo."

Creative Tourism Activities Organized by VAGAR Walking Tours. Adding to its portfolio of cultural activities, within CREATOUR, this microentrepreneurial venture developed a creative tourism product called 'Play Évora'. Play Évora is an educational kit for families visiting the city of Évora that has been designed as a game to involve interplay between the users and elements of the landscape, which leads to the discovery of the city. The activity is structured in a flexible way that aims to respect the rhythm of each family and to extend their stay in Évora. The Play Évora kit of 
activities can be ordered and acquired at local hotels and stores. The game features creative activities regarding the interpretation of heritage sites and curiosities of the city and it is structured into thematic books (local culture and gastronomy) that are directed to various age ranges, both teenagers and younger children. A third book for the parents explains historical details and provides answers to the quizzes.

\section{INSERT FIGURE 3 AROUND HERE}

Figure 3. Children with the Play Évora Book of Activities (left) and Street Art from "100 Pavor" representing the Temple of Diana (right). (Source: Sara Albino)

Activities Being Shaped by Place. Activities organized by VAGAR Walking Tours are inspired by and represent local cultural heritage, contemporary artistic expressions, and the community - 'place' is the primary content of the creative tourism offer. Tourists' experiences are embedded in the geographical, spatial, and historical-cultural contexts of the city. For example, Play Évora activities involve interactions with a local ceramist who owns the museum Aldeia da Terra and 'Queens' traditional pastry shop. Play Évora exhibits and is made up of Alentejo's main traits of regional culture in an attempt to characterize and transmit knowledge about the traditional and modern "spirit of place." Play Évora is place-based in its core design and contributes to place-making through a participatory approach that allows knowledge flows to occur between the company, tourists, and local businesses. The Play Évora approach to place-making is sustained in the interdependencies with local social actors, not only in the promotion and distribution of kits but also in the implementation of the tourist experience, wherein tourists are encouraged to interact with people from local businesses. The various actors in VAGAR Walking Tours, those who promote the experiences as well as those who provide them, are also contributors to place-making as they adapt their language and make business-tobusiness engagements according to the interests of the target-public. Through these networks of collaborators, an array of independent actors are jointly creating new narratives for their place.

Activities Shaping Place. Activities also shape place as they create new routes and personal perspectives of the city. For instance, Play Évora has a focus on urban street art through a cooperation with the Cultural Association 100 Pavor, which reinterprets elements of the history of Évora and interprets them as graffiti interventions on urban elements such as public electricity boxes. The users of Play Évora are also invited to actively participate and share their own creativity through social media, to follow the urban art elements related to local legends and the history of Évora, and to draw in the notebooks of the activity kit. As Melanie notes, "in the activity books, we have charades and we ask the children to discover and draw elements of the city. We thought of finding a place where the users could make their [own] street art."

The place is also shaped through the alternative patterns of tourism consumption that have emerged, which have been encouraging different types of niche tourism and visitors in Évora. These types of tourists include smaller groups that are interested in embedding local experiences constructed at their own pace, and families with young and/or teenage children. Play Évora contributes, in a small way due to its micro-scale, to profile Évora as a family-friendly creative tourism destination, thus differentiating itself from Évora's predominant image as a mass tourism destination. The idea of seeing the city as a place for family time and bonding not only gives new positive dimensions to the city's tourism profile but also enhances the interaction between tourists and the local community, extends visitors' length of stay, and increases the number of repeat visitors who engage with VAGAR Walking Tours' activities.

Visitors led by the Play Évora kit of activities help to shape the future tourism profile of the place. In this process of co-creation, visitors' experiences help shape new tourism products through symbolic interaction (Bruner, 1989). These city explorations allow visitors to focus on particular elements of the city landscape and in situ 'performances', loosely choreographed by VAGAR Walking Tours, which have the ability to slowly influence the image and the 'shape' of a mature cultural destination that has been subject to mass cultural tourism since its classification as UNESCO World Heritage. As Richards (2011) has pointed out, tourism companies develop creative tourism experiences to engage 
with untapped consumer markets. In the case of VAGAR Walking Tours, the offer of Play Évora kits reflects these microentrepreneurs' strategic desire to target families with a differentiated product. VAGAR Walking Tours' ability to create new activities and encourage new perspectives on their place can generate new tourism demands and publics, all of which potentially contribute to the development of a richer and more diversified destination.

\section{CONCLUSION}

Creative tourism microentrepreneurs are inspired by, actively engage with, and influence the place in which they operate. The cases examined here illustrate some of the nuances of this complex process. This research finds that 'place' in its expansive meaning, including geographical, cultural, and social landscapes, is an essential element throughout the creative tourism development and implementation processes, serving as a source of inspiration to design creative tourism offers as well as influencing the ways in which the offers operationalize and evolve over time. Furthermore, in the design and implementation of these products and the activation of ideas, the activity and aspirations of these microentrepreneurs define and propel incremental developments and pathways forward, in ways embedded in networks both local and global, and highly sensitive to multifaceted features of their locality. These processes co-influence the nature of the microentrepreneur's business, the creative tourism products produced and, over time, the dimensions of place with which they are involved.

Taking a place-based approach reveals how the social and ecological environments intimately shape the way in which microentrepreneurs operate, rather than existing as exogenous forces to which organizations must respond to while pursuing profits. Drawing on knowledge created within the context of the CREATOUR project, this chapter examines two creative tourism microentrepreneurial case studies. We found that the choices made by these microentrepreneurs in developing their creative tourism offers are specifically influenced by the place in which they operate. In the case of VIC//Aveiro Arts House, the lack of cultural programming and connections among local artists in Aveiro, especially in the area of sound art, created a niche for the development of creative tourism workshops focusing on sound. Knowledge flows (Reed et al., 2017) stemming from the microentrepreneur's personal interests and networks in this artform and, more specifically, the hosting of artists' residencies meant that Hugo had the power and social capital to attract and 'capture' the resources needed in order to enable these sound-related workshops to take place. In the case of VAGAR Walking Tours, we see how activities appealing to more active niche markets were needed in Évora. Local social and business networks provided the network that made the creation of interactive family-focused creative tourism experiences feasible. These cases indicate that destinations aspiring to be adaptable and competitive should nurture their local creative networks and microentrepreneurs and engage with them to develop interesting and genuine creative tourism experiences. Furthermore, destinations should provide support to local creatives so that they can apply their ingenuity and perspectives to enhancing and diversifying local tourism offers.

The characteristics of visitors also shape the creative tourism activities offered in a destination. For example, the varying types of people who visit Aveiro in different seasons led Hugo to create 'seasonal' creative tourism workshops that are longer during the winter and shorter during the summer. At the same time, these activities can be perceived as place-shaping and tourism-enhancing, as people living outside Aveiro participate in the two-day workshops too, thus increasing the number of visitors to Aveiro who stay more than just the usual day-trip. Hosting artist residencies at VIC//Aveiro Arts House and attracting travelling artists who put on performances there and lead creative tourism workshops has proven to be a powerful synergetic strategy. At the same time, this means that the topics explored in the workshops are dependent on the artists' interests and that the timing of the workshops are dependent on the artists' availability, especially in the case of visiting artists who are only around for a short time period. VAGAR Walking Tours' creative tourism offer (Play Évora) takes on a dynamic form in terms of the activities and interactions it encourages and supports, which are played out in different ways depending on the participants and their spontaneous actions and encounters. The conversations between visitors and local shopkeepers and the processes within various creative activities lead to increased knowledge through a closer observation of the place. Consequently, Play Évora is shaping its place through offering a novel platform for meaningful 
resident-tourist interactions. Simultaneously, since this activity is specifically geared towards families visiting Évora, it is enabling this tourist market segment to become more integrated into Evora's tourism ecosystem. These findings reveal that once local microentrepreneurs begin to interact with tourists, they are very innovative, developing differentiated offerings that target untapped market segments. Accordingly, microentrepreneur support processes might focus on business management methods to help them pursue their business innovations in feasible ways, rather than prescriptive marketing advice.

Microentrepreneurial creative tourism activities can act as the 'seed' to inspire future actions. In the case of Évora, VAGAR Walking Tours has been asked to develop a version that can be used in local school education, integrating a creative approach to articulating the local in an educational tool to learn about the city. Through this kit of activities, local school children will engage with their community's cultural heritage in a participatory and creative way. In Aveiro, VIC//Aveiro Arts House aims to foster social change by creating a space in cooperation with the municipality and university to bring locals, the temporary population (students and researchers), and tourists together in meaningful ways that are not necessarily defined by commercial relations. In enacting this dream, Hugo perceives entrepreneurship as more than a site of exchange of labor and the economy as a cultural and social formation (Ateljevic and Doorne, 2003). Furthermore, by envisioning a series of creative tourism workshops that teach cultural management to locals in order for them to also hold similar workshops or cultural events, Hugo aims to help change Aveiro's social, cultural, and touristic landscape by encouraging a critical mass of tourism offers to be sustainably generated. This shows that creative tourism microentrepreneurship can jumpstart a chain reaction of local engagement with tourism. In this dynamic, local communities are active agents understanding, engaging with, and benefitting from tourism.

In closing, we observe that today's entrepreneurship literature focuses on entrepreneurs either in urban areas or in rural areas. In the contemporary context where the effects of globalization and capitalism increasingly push people to live in the peripheries, taking advantage of lower-priced housing but maintaining strong links with urban centres, research that focuses on the small city context is urgently needed for a just representation of today's reality. At the practical level, this study of creative tourism entrepreneurship in small cities can help to identify ways to help sustainably develop these areas by focusing on how microentrepreneurs interact with place. Furthermore, microentrepreneurs in the field of creative tourism are taking remarkedly different approaches: an artistically-driven core drives VIC//Aveiro Arts House, while a touristic context activates VAGAR Walking Tours in their individual trajectories. Understanding these microentrepreneurs requires close and careful 'unlayering' of the complexities of their motivations, inspirations, interactions, and other influences and dynamics within the place they operate.

\section{ACKNOWLEDGEMENTS}

This article was developed within the framework of a research project entitled 'CREATOUR: Creative Tourism Destination Development in Small Cities and Rural Areas' (Project 016437), which is supported by the Portuguese Foundation for Science and Technology (FCT/MEC) through national funds and cofunded by FEDER through the Joint Activities Programme of COMPETE 2020 and the Regional Operational Programmes of Lisbon and Algarve. The authors would like to thank the interviewed participants for their precious time and valuable insights and the editors for their helpful comments.

\section{REFERENCES}

Ahl, H., \& Marlow, S. (2012). Exploring the dynamics of gender, feminism and entrepreneurship: Advancing debate to escape a dead end?. Organization, 19(5), 543-562.

Ateljevic, I., \& Doorne, S. (2003). Unpacking the local: A cultural analysis of tourism 
entrepreneurship in Murter, Croatia. Tourism Geographies, 5(2), 123-150.

Bakas, F. (2014). Tourism, female entrepreneurship and gender: Crafting new economic realities in rural Greece. PhD thesis. Otago University, New Zealand. http://hdl.handle.net/10523/5381.

Bakas, F. E. (2017). Community resilience through entrepreneurship: The role of gender. Journal of Enterprising communities: People and places in the global economy, 11(1), 61-77. https://doi.org/10.1108/JEC-01-2015-0008.

Bakas, F. E., \& Duxbury, N. (2018). Development of rural areas and small cities through creative tourism: The CREATOUR project. Anais Brasileiros de Estudos Turísticos (ABET), 8(3), 74-84.

Bakas, F. E., Duxbury, N., \& Castro, T. V. (2019). Creative tourism: Catalysing artisan entrepreneur networks in rural Portugal. International Journal of Entrepreneurial Behavior \& Research, 25(4), 731-752. https://doi.org/10.1108/IJEBR-03-2018-0177.

Barker, D. K., \& Kuiper, E. (2003). Introduction. In D. Barker, \& E. Kuiper (Eds.), Toward a feminist philosophy of economics. New York: Routledge.

Bell, D., \& Jayne, M. (2010). The creative countryside: Policy and practice in the UK rural cultural economy. Journal of Rural Studies, 26(3), 209-218. https://doi.org/10.1016/j.jrurstud.2010.01.001.

Bruner, E. (1989). Tourism, creativity, and authenticity. Studies in Symbolic Interaction, 10, 109-114.

Bygrave, W. D. (1997). The portable MBA in entrepreneurship. New York: J. Wiley \& Sons.

Chandy, R., \& Narasimhan, O. (2011). How micro-entrepreneurs could change the world. Business Strategy Review, 22(1), 52-55.

Cresswell, T. (2006). Place: A short introduction. Malden, MA: Blackwell. https://doi.org/10.4135/9781412952422.

Davenport, M. A., \& Anderson, D. H. (2005). Getting from sense of place to place-based management: An interpretive investigation of place meanings and perceptions of landscape change. Society \& Natural Resources, 18(7), 625-641. https://doi.org/10.1080/08941920590959613.

Duxbury, N. (2020). Catalyzing creative tourism in small cities and rural areas in Portugal: The CREATOUR approach. In K. Scherf (Ed.), Creative tourism and sustainable development in smaller communities. Calgary: University of Calgary Press.

Duxbury, N., \& Richards, G. (2019). Towards a research agenda for creative tourism: Developments, diversity, and dynamics. In N. Duxbury \& G. Richards (Eds.), A research agenda for creative tourism (pp. 1-14). Cheltenham, UK: Edward Elgar Publishing.

Duxbury, N., Silva, S., \& Castro, T. V. (2019). Creative tourism development in small cities and rural areas in Portugal: insights from start-up activities. In D. A. Jelinčić \& Y. Mansfeld (Eds.), Creating and managing experiences in cultural tourism. Singapore: World Scientific Publishing.

Flyvbjerg, B. (2011). Case study. In N. K. Denzin \& Y. S. Lincoln (Eds.), The SAGE handbook of qualitative research (pp. 301-312). 2nd edn. Thousand Oaks, CA: Sage.

Di Gregorio, D. (2017). Place-based business models for resilient local economies: Cases from Italian slow food, agritourism and the albergo diffuso. Journal of Enterprising Communities: People and Places in the Global Economy, 11(1), 113-128. https://doi.org/10.1108/JEC-02-2015-0016.

Hildreth, P., \& Bailey, D. (2014). Place-based economic development strategy in England: Filling the missing space. Local Economy, 29(4-5), 363-377. https://doi.org/10.1177/0269094214535712. 
Hollingshead, K., Ateljevic, I., \& Ali, N. (2009). Worldmaking agency-worldmaking authority: The sovereign constitutive role of tourism. Tourism Geographies, 11(4), 427-443.

Korsgaard, S., Ferguson, R., \& Gaddefors, J. (2015). The best of both worlds: How rural entrepreneurs use placial embeddedness and strategic networks to create opportunities. Entrepreneurship \& Regional Development, 27(9-10), 574-598. https://doi.org/10.1080/08985626.2015.1085100.

McKeever, E., Anderson, A., \& Jack, S. (2014). Social embeddedness in entrepreneurship research: The importance of context and community. In E. Chell \& M. Karataş-Özkan (Eds.), Handbook of research on small business and entrepreneurship (pp. 222-236). Cheltenham, UK: Edward Elgar Publishing.

Mueller, A., \& Schade, M. (2012). Symbols and place identity: A semiotic approach to internal place branding - case study Bremen (Germany). Journal of Place Management and Development, 5(1), 8192. https://doi.org/10.1108/17538331211209068.

PORDATA. (2011). Resident population, according to the Census: Total and by size of population centre.

https://www.pordata.pt/en/Municipalities/Resident+population++according + to + the + Census + total + an $\mathrm{d}+$ by + size + of + population+centre- 24 .

Reed, M. S., Allen, K, Attlee, A, Dougill, A. J., Evans, K. L., Kenter, J. O., Hoy, J., McNab, D., Stead, S. M., Twyman, C., Scott, A. S., Smyth, M. A., Stringer, L. C., \& Whittingham, M. J. (2017). A place-based approach to payments for ecosystem services. Global Environmental Change, 43, 92106. https://doi.org/10.1016/j.gloenvcha.2016.12.009.

Richards, G. (2011). Creativity and tourism: The state of the art. Annals of Tourism Research, 38(4), 1225-1253. https://doi.org/10.1016/j.annals.2011.07.008.

Richards, G. (2018). Cultural tourism: A review of recent research and trends. Journal of Hospitality and Tourism Management, 36, 12-21. https://doi.org/10.1016/J.JHTM.2018.03.005.

Serra, J., Marujo, M. N., Borges, M. R., \& Caldeira, R. (2017). Perfil do visitante do centro histórico de Évora: 2010, 2015, 2017. Évora: Universidade de Évora.

Stock, M. (2006). Construire l'identité par la pratique des lieux. In A. De Biase \& C. Alessandro (Eds.), “Chez nous" : Territoires et identités dans les mondes contemporains (pp. 142-159). Paris: Editions de la Villette.

Townsend, L., Wallace, C., Smart, A., \& Norman, T. (2016). Building virtual bridges: How rural micro-enterprises develop social capital in online and face-to-face settings. Sociologia ruralis, 56(1), $29-47$.

Vial, V., \& Hanoteau, J. (2015). Returns to micro-entrepreneurship in an emerging economy: A quantile study of entrepreneurial indonesian households' welfare. World Development, 74, 142-157. https://doi.org/10.1016/J.WORLDDEV.2015.04.008.

Yin, R. K. (2009). Case study research. 4th edn. Thousand Oaks, CA: Sage. 


\section{CREATOUR Network}

40 participating organisations (pilots)

9 municipalities

11 entrepreneurs

16 cultural or local development associations

3 partnerships:

(1 national museum+2 municipalities;

1 company+3 municipalities;

1 company+1 musuem)

1 informal network

\section{Research centres:}

CES -Centre for Social Studies, Centro (coordinator); Lab2PT- Norte; CIDEHUS - Alentejo; CIEO - Algarve; Dinãmia'CET-Lisbon

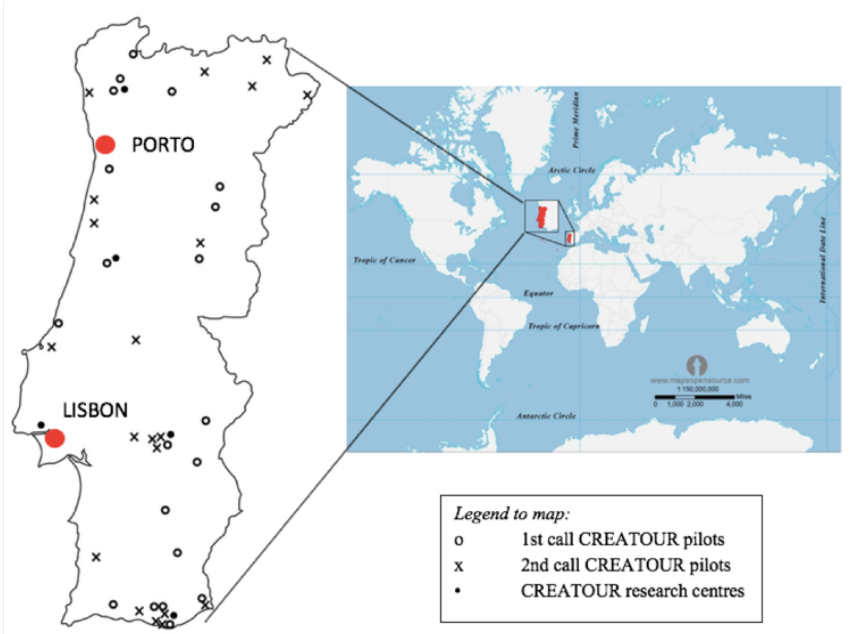

Figure 1. CREATOUR Research Centres and Pilots (Participating Organizations) in Portugal

Source: CREATOUR and www.mapsopensource.com

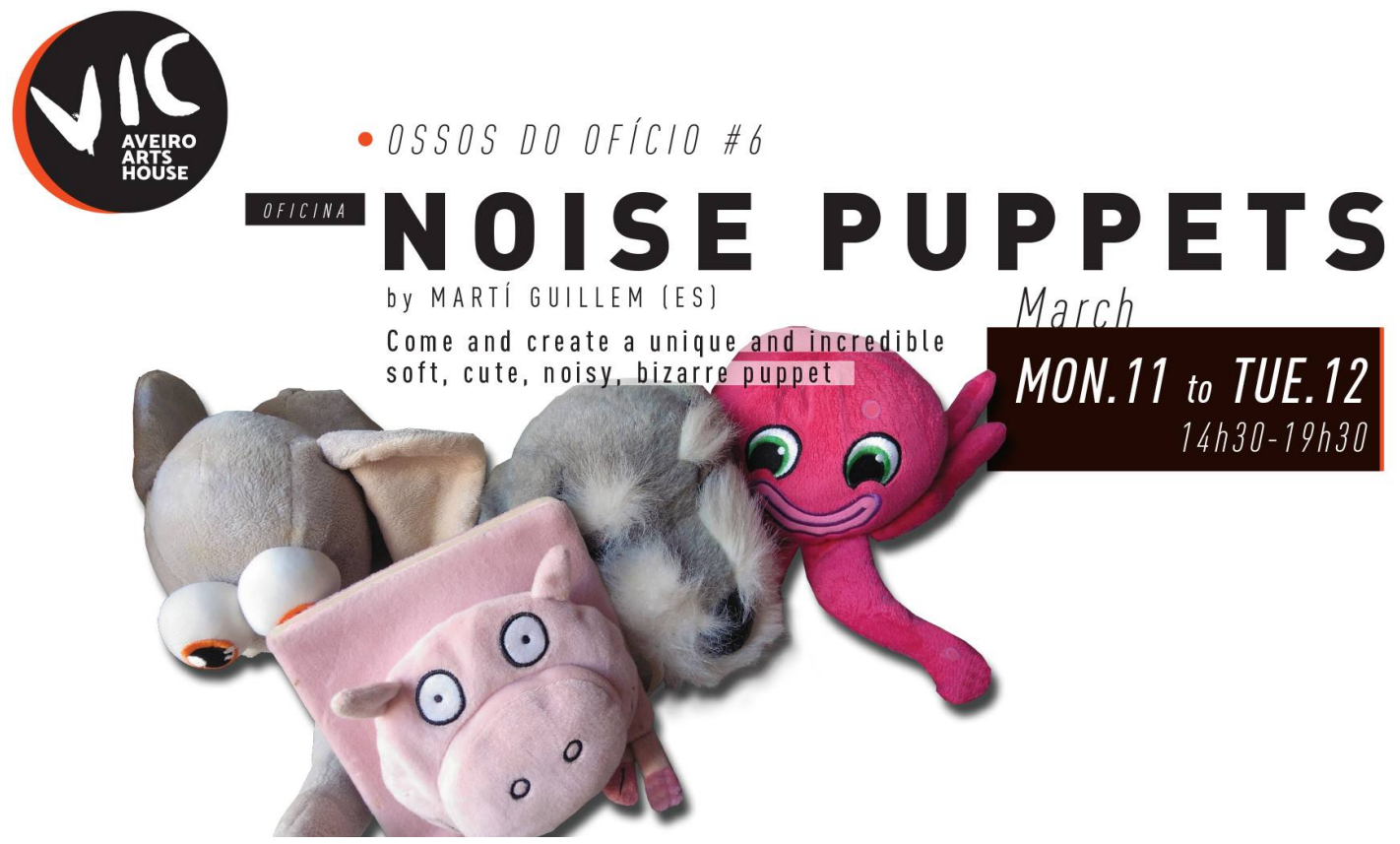

Figure 2. Poster for the Noise Puppets Workshop at VIC//Aveiro Arts House

Source: VIC//Aveiro Arts House 


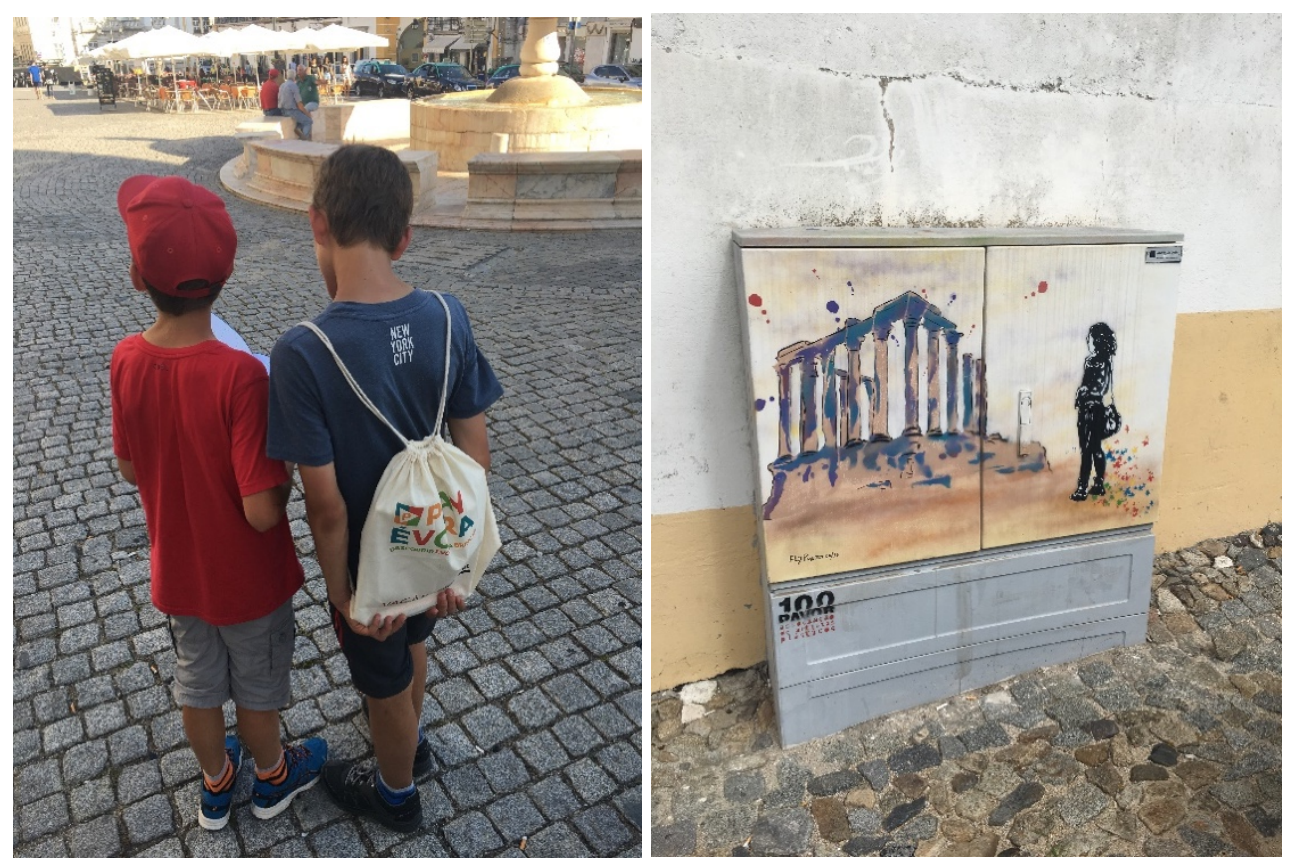

Figure 3. Children with the Play Évora Book of Activities (left) and Street Art from "100 Pavor" Representing the Temple of Diana (right)

Source: Sara Albino 